DOI: https://doi.org/10.32839/2304-5809/2021-11-99-36

УДК 304.2/796.011.1

Гнидюк О.П., Мороз Х.В.

Національна академія Державної прикордонної служби України імені Богдана Хмельницького

\title{
ГЕНДЕРНА РІВНІСТЬ: РІВНІ УМОВИ ДЛЯ СЛУЖБИ ТА ФІЗИЧНИХ НАВАНТАЖЕНЬ У ВІЙСЬКОВИХ ФОРМУВАННЯХ
}

\begin{abstract}
Анотація. У статті розглянуто систему гендерної рівності в сучасній армії, досліджено розвиток фрізичної підготовки в Національної академії ДПСУ та проведено порівняльну характеристику з іншими правоохоронними органами стосовно впливу на гендер та рівних умов для несення служби військовослужбовцями, виходячи $з$ цього поставленні для з'ясування наступні завдання. З'ясовано, що протягом останнього десятиліття гендерна рівність стає все більш актуальною проблемою для армії. Це завершилося у 2018 році, коли було знято обмеження для жінок, які служать у фрронтовій піхоті та спецпідрозділах ближнього бою. Провівши аналіз літератури, законодавства України та міжнародних нормативно-правових документів встановлено, що кожна жінка, як і чоловік має право обирати професію та реалізовувати себе у будь-якій copepi , головне бути впевненим в своїх силах та віддаватись своїй справі повністю. Військова дормма, зброя, залізна дисципліна та чітке виконання наказів - це звичайні атрибути професії, притаманні для людей у погонах. Жінок, що свідомо пов'язують своє життя із армією стає дедалі більше. Гендерний підхід у військовій сфері притаманний усім країнам-членам НАТО. Альянс допомагає українській державі з імплементацією національного плану дій щодо резолюції ООН 1325. Цей міжнародний документ забезпечуе активну участь жінок у військових і миротворчих процесах. У ДПСУ досить великий відсоток персоналу складають жінки, понад 25 \% жінок проходять військову службу в прикордонному відомстві, 3 яких близько $12 \%$ складає офіцерський склад. Для того, щоб дослідити дане питання, було проаналізовано вже опубліковані праці з цього питання , а також проведено аналіз щодо вимог фізичної підготовки. Виходячи 3 проведеного аналізу, метою дослідження визначено, дослідити та вдосконалити систему гендерної рівності в сучасній армії та розвиток фізичної підготовки, Завдяки проведеному дослідженню, ми довели, що повинні висуватись рівні умови для несення служби та вступу до ВВНЗ жінок та вдосконалення системи фрізичної підготовки, яка на даних момент є на етапі рефрормації. Перспективи подальших досліджень полягають у дослідженні та узагальненні досвіду реалізації гендерної політики країн Свропи, порядок проходження служби в військових формуваннях та правоохоронних органах жінками.
\end{abstract}

Ключові слова: гендерна рівність, жінки-військовослужбовці, фрізична підготовка, військова служба, прикордонна служба.

Gnydiuk Oleksandr, Moroz Khrystyna The National Academy of the State Border Guard Service of Ukraine named after Bohdan Khmelnytskiy

\section{THE GENDER EQUALITY: THE EQUAL CONDITIONS FOR SERVICE AND PHYSICAL EXERCISES IN MILITARY FORMATIONS}

Summary. The article considers the system of gender equality in the modern army, examines the development of physical training in the National Academy of the State Border Guard Service of Ukraine named after Bohdan Khmelnytskiy and compares with other law enforcement agencies on the impact on gender and equal conditions for military service, based on this task to clarify the following tasks. Gender equality has been found to be an increasingly pressing issue for the military over the past decade. This ended in 2018 , when restrictions were lifted for women serving in frontline infantry and special combats. After analyzing the literature, legislation of Ukraine and international legal documents, it is established that every woman, like men, has the right to choose a profession and realize themselves in any sphere, the main thing is to be confident in their abilities and give themselves completely. Military uniform, weapons, strong discipline and strict execution of orders are the usual attributes of the profession, inherent in people in uniform. There are more and more women who consciously connect their lives with the army. Gender approaches in the military sphere are common to all NATO member countries. The Alliance is assisting the Ukrainian state in the implementation of the National Action Plan on UN Resolution 1325. This international instrument ensures the active participation of women in military and peacekeeping processes. The large percentage of staff, women, more than $25 \%$ of women serve in the border service, of which about $12 \%$ are officers in the State border guard service of Ukraine. In order to investigate this issue, the already published works on this issue were analyzed, as well as an analysis of the requirements for physical training. Based on the analysis, the purpose of the study is to identify, investigate and improve the system of gender equality in the modern army and the development of physical training. at the moment there is a stage of reformation. Prospects for further research are to study and summarize the experience of implementing the gender policy of European countries, the order of service in military formations and law enforcement agencies by women.

Keywords: gender equality, women servicemen, physical training, military service, border service.

Постановка проблеми. В сучасному світі і без винятку в армїі довгий період піднімалось питання щодо гендеру, в наш час удосконалюеться програма щодо рівних умов вступу до вищих військових навчальних закладів. Національна академія Державної прикордонної служби України (далі - НАДПСУ) є однім з передових закладів, щодо розвитку гендеру, адже кожного року 
удосконалює систему навчання, задля рівних умов навчання як для дівчат, так і для хлопців.

Аналіз останніх досліджень і публікацій. У роботі проведено аналіз наукових праць, таких дослідників як: Голованова Т.П., Палагнюк M.M., Рубан О.В., Вороніна А.О., Кротіков В.П., Малюга В.М., Топальський В.Л., Голуб А., Ветров І., Андресюк П.Б., Срмолаєва Т.В. та Шваб К.В., Калагін Ю.А. та інші. Однак питання гендерної рівності у Вищих Військових Навчальних Закладах (далі - ВВНЗ) ще не досліджувалося в сучасній літературі.

Виділення не вирішених раніше частин загальної проблеми. Питання розвитку фpiзичної підготовки та гендерної рівності в ВВНЗ вимагає окремого дослідження. Вдосконалення системи фрізичної підготовки, для рівних умов щодо несення служби та вдосконалення фрізичних якостей жінок-військовослужбовщів, задля вдосконалення гендерної рівності.

Мета статті. Теоретично обгрунтувати систему гендерної рівності в сучасній армії, дослідити розвиток фізичної підготовки в НАДПСУ та провести порівняльну характеристику 3 іншими правоохоронними органами стосовно впливу на гендер, та рівних умов для несення служби військовослужбовцями. У зв'язку з цим поставлені завдання:

- дослідити гендерну рівність в сучасній армії та ВВНЗ;

- проаналізувати вимоги щодо фрізичної підготовки курсантів та військовослужбовців;

- проаналізувати літературні джерела, щодо гендерної рівності в сучасній армії та вимоги які виносяться до жінок-військовослужбовців.

Виклад основного матеріалу. Протягом тривалого часу чоловіки створювали історичну картину світу, висловлюючи свої погляди на навколишню дійсність, устрій ідеальної сімі, місце і роль жінки в соціальному просторі. Противники гендерної рівності пояснювали це тим, що жінки не могли служити в армії ні морально, ні фрізично. Сучасні збройні сили більшості країн світу немислимими без представниць прекрасної статі [1, с. 14-16]. Це об'ективний процес фемінізації суспільства, що характеризуеться посиленням ролі та впливу жінки в армії. Щоб захистити права жінок, дослідники провели низку соціологічних досліджень, які показали, що жінки та чоловіки однаково страждають від психологічного та фрізичного впливу та напруженого графіка. Сьогодні ні в кого не викликає сумніву щодо необхідності зарахування жінок до військ як повноцінних військовослужбовців [2, с. 73-83]. Фемінізація армії $є$ специфрічною складовою об'ективного процесу фемінізації суспільства і виражається посиленням ролі та впливу жінки в армії, а також функціональною залежністю останньої від ступеня особистісного потенщіалу в армії. жінки-військовослужбовці [3, с. 33]. Актуальність проблеми обумовлена збільшенням кількості жінок-військовослужбовців в армї; розширення кола військово-облікових спеціальностей і посад, які займають жінки-військовослужбовці; домінування застарілих стереотипів про місце та роль жінки у Збройних Силах.

У 1989 році Канада відкрила всі військові пости для жінок, за винятком служби на під- водних човнах, де жінкам дозволено служити з 2000 року. Повна інтеграція жінок до канадських збройних сил - завдання не 3 легких. Є багато питань, пов'язаних із фрізичними гендерними відмінностями та навантаженнями. Нещодавні канадські дослідження показують, що громадянське суспільство все ще не сприймає жінок у бойових ролях.

Більшість чоловіків загалом позитивно реагують на присутність жінок в армї, вважаючи їх рівноправними військовослужбовцями. Гендерна політика у збройних силах передбачає не лише рівні права для військовослужбовців обох статей, але також, що не менш важливо, рівні обов'язки [4, с. 133-151]. У зв'язку з цим респондентам було запропоновано відповісти на запитання «Чи потрібно при організації служби жінок-військовослужбовців враховувати їх фpiзiологічні, психологічні особливості та репродуктивні функції?». Аналіз відповідей показуе, що переважна більшість чоловіків $(62,08 \%)$ та жінок (75,00\%) вважають, що так, це необхідно враховувати. Слід зазначити, що відсоток жінок, які так вважають, значно вищий, ніж відсоток чоловіків. $26,41 \%$ опитаних чоловіків і $18,75 \%$ жінок вважають за необхідне частково врахувати фрізіологічні, психологічні особливості та репродуктивні функції жінок під час організації військової служби. У той же час цю відповідь вже підтримують більше чоловіків. 10,76\% опитаних чоловіків і 6,25\% опитаних жінок категорично заперечують [5]. «Дослідження військових психологів показують, що присутність жінок у колективі значно пом'якшуе морально-психологічну атмосфреру, змушує командирів бути стриманими, а головне - зростає культура взаємин між військовослужбовцями в самому колективі. Соціологічні дослідження за минулі 10 років показують, що саме жінки-військовослужбовці найретельніше виконують свої обов'язки» [6, с. 116-119].

Курсантки Національної академії Державної прикордонної служби України імені Богдана Хмельницького систематично займаються спортом, та покращують власні показники, адже фізична підготовка, є однією з складових задля перевірки та визначення придатності до служби. Дівчата як і хлопщі в однакових умовах вступають в наш ВВНЗ, щороку кількість дівчат збільшуеться, як приклад $е$ спеціальність «Безпека державного кордону» на яку ще два роки тому не могли передбачити та уявити, що буде конкурс між абітурієнтами 3 числа дівчат на вступ до НАДПСУ. Вже на сьогодні там навчаеться 10 дівчат на 1 курсі та 19 на другому, а це свідчить про готовність їх виконувати завдання на рівні 3 чоловіками, чи те стосується фрізичної підготовки чи завдань, що безпосередньо відносяться до несення служби. Щодня жінки своїми діями здатні підтвердити, що військова служба, це не лише чоловіча справа.

Курсантки НАДПСУ - є прикладом гендерної рівності в армії, адже в Альма-матер прикордонної служби має три фракультети, і так склалось історично, що на фракультеті Безпеки Державного Кордону навчались лише хлопщі, адже викладаються дисципліни які безпосередньо відносяться до охорони та безпеки державного кордону. Проте, 2020 року фракультет оголосив про набір дівчат 
про що ми говорили вище, і ось уже протягом двох років, дівчата в нащіональній академії мають право вступати на будь-який з трьох фракультетів, та обирати спеціальність яка їм до душі.

Фізична підготовка для курсантів ВВНЗ є надзвичайно важливою, дівчата на рівні з хлопцями здають нормативи, мають змогу брати участь та вдосконалюватись та представляти НАДПСУ як на всеукраїнських та міжнародних змаганнях в різноманітних видах спорту, які представлені під час навчання. Закладено ще 3 давніхдавен, що жінки і справді не здають нормативи такі як - підтягування на перекладині, та здають нормативи 31 кілометру - натомість чоловіки біжать - 3 кілометри, проте як ми можемо спостерігати система фрізичної підготовки вдосконалюється, і для жінок також змінюються нормативи. 31 січня 2022 року Збройні Сили України керуватимуться новою Інструкцією 3 фрізичної підготовки, зокрема по-новому проводитимуть й ощінювання - відтепер щокварталу. Зазначається, що інструкція передбачає ведення щодо кожного військовослужбовця картки обліку фрізичної підготовки, а також 15 різних відомостей, журналів та облікових фрорм. У новій Інструкції унормували порядок перевірки фрізичної підготовленості - всі військовослужбовці з 2022 року перевірятимуться щокварталу. Загальна фрізична підготовленість перевірятиметься за допомогою тесту.

Для жінок віком до 30 років так само передбачено біг на 3 кілометри, дві силові вправи - згинання та розгинання рук в упорі лежачи, згинання та розгинання тулуба. Для жінок 30-39 років - ті ж самі дві силові вправи та біг на 2 кілометри. I для тих, кому більше ніж 40 років, - ідентичні силові вправи та біг уже на 1 кілометр. Гендерна рівність має на увазі врахування інтересів, потреб і пріоритетів як жінок, так і чоловіків, визнаючи розмаїття різних груп жінок і чоловіків. Гендерна рівність не $є$ проблемою жінок, але має зачіпати і турбувати як чоловіків, так і жінок. Рівність між жінками та чоловіками є одночасно правом людини і $є$ попередньою умовою і показником для постійного, соціально орієнтованого розвитку [7]. Для едективного впровадження гендерного компоненту у військовій освіті, нормативно-правових актах, стратегічному і оперативному командуванні важливо знати і враховувати загальні положення, підходи та особливості сектору безпеки. Окрім загальних підходів важливою $є$ концепція рівно правної участі жінок, якої зазвичай не дотримуються в структурах сектору безпеки. Це пояснюеться тим, що протягом тривалого часу жінок не розглядали як рівноправних в доступі до військової служби [8]. Важливо розуміти, що військові конфлікти здійснюють значний вплив на життя жінок і чоловіків. При цьому, достатньо велика частина жінок не $є$ пасивними спостерігачками. Вони виконують активні фрункції - служать у збройних силах, правоохоронних органах, добровольчих батальйонах. Жінки складають більшість волонтерських груп та організацій, надаючи допомогу як військовим, так і громадянам, що залишилися на тимчасово окупованій території, а також внутрішньо переміщеним особам [9].

Слід зазначити, що жінки які беруть участь у воєнних діях, так само як і чоловіки перебувають під захистом міжнародного гуманітарного права, 3 того моменту, коли вони потрапляють під владу противника. Вперше у світі жінки стали повноправними військовослужбовцями 3 відповідним офіційним статусом 1895 року в Канаді, коли їх приймали на військову службу в мирний час не тільки у структури забезпечення, а й у бойові частини [10].

Жінки як військовополонені належать до вразливої категорії жертв збройних конфліктів та їх наслідків. Останніми роками помітно зменшився інтерес до питання захисту жінок-військовополонених. Значною мірою це призвело до слабкого висвітлення подій, які відбуваються закордоном, пов'язаних з дотриманням їх прав під час полонення, що повинно викликати серйозне занепокоення міжнародного співтовариства.

Слід зазначити, що саме прагнення миру, очікування миру стали головною мрією та ціллю України з часів військової агресії Російської Федеращії. Але мир не приходить сам по собі. Йог потрібно будувати, зберігати та укріплювати. Важливу роль у цьому відіграють жінки [11].

Висновки i пропозиції. Вважається, що збройні сили зараз зазнають певної трансформації, тому фрізична сила та агресія, які традиційно вважаються чоловічою рисою, втрачають свою цінність і все частіше застосовуються інтелектуальні тактики. Дискусї про те, чи варто жінкам служити в збройних силах, як правило, зосереджуються виключно на фрізичній силі чи гендерній рівності, а не на тому, чи можуть вони насправді зробити армію ефективнішою. Наявність більш різноманітних збройних сил відображає складність зон конфрлікту, в яких вони діють. Бойові дії часто ведуться в густонаселених районах, а не на віддалених фрронтах, тому військові не повинні обмежуватися прямими військовими діями з ворогом, а й все більше змушені вчитися будувати відносини 3 широким колом людей чоловіками, жінками та дітьми в зоні бойових дій і районах, які знаходяться в безпосередній близькості від них.

Перспективою подальших досліджень є вивчення та узагальнення досвіду реалізації гендерної політики країн Європи, порядок проходження служби в військових формуваннях та правоохоронних органах жінками.

\section{Список літератури:}

1. Голованова Т.П. Методологічні підходи та методи дослідження гендерних питань в освіті. Гендерна парадигма освітнього простору. Кривий Ріг : ВЦ КГПІ ДВНЗ «КНУ», 2015. № 1. С. 14-16.

2. Палагнюк М.М. Гендерна проблематика: виклики сучасності». Гуманітарний вісник Запорізької державної інженерної акаделії. 2015. № 60. С. 73-83.

3. Рубан О.В. Реалії та перспективи гендерного партнерства в Україні на початку ХХІ століття (світоглядний аспект). Київ : НАН України, 2012. С. 33.

4. Вороніна О.А. Гендерне рівняння як структурний елемент державної політики в скандинавських країнах. Новий погляд. 2014. № 4. С. 133-151. 
5. Кротіков В.П., Малюга В.М., Топальський В.Л. Гендерна політика у Збройних Силах України: проблеми теорії та практики. Київ : НДЦ ГП ЗСУ, 2012.

6. Клименко Н.Г. Роль і місце жінки - військовослужбовця в Україні. Еконоліка і держава. 2014. С. 116-119.

7. Марценюк Т. «Невидимий батальйон»: участь жінок у військових діях в АТО (соціологічне дослідження). 2016. URL: http://ekmair.ukma.edu.ua/bitstream/handle/123456789/7746/Martsenyuk_Nevydymyi_bataloin.pdf (дата звернення: 20.11.2021).

8. Голуб А. Обов’язковий призов жінок у армію: міжнародний досвід та Україна. 2017. URL: https://uain.press/ articles/obovyazkovyj-pryzov-zhinok-u-armiyu-mizhnarodnyj-dosvid-ta-ukrayina-605256 (дата звернення: 21.11.2021).

9. Чи потрібні жінки на війні? URL: https://uavarta.org/2015/05/14/chi-potribni-zhinki-na-viyni/ (дата звернення: 21.11.2021).

10. Ветров I. Жінки в армії: ЗСУ і світовий досвід. 2016. URL: https://ukraine.segodnya.ua/ua/ukraine/zhenshchinyv-armii-vsu-i-mirovoy-opyt-689801 (дата звернення: 21.11.2021).

11. Кротиков В.П., Малюга В.М., Топальський В.Л. Актуальні проблеми гендерної політики Збройних сил України : навч. посібник / за заг. ред. Андресюка Б.П. Київ : НДЦ ГП ЗС України, 2011. 112 с.

\section{References:}

1. Holovanova T.P. (2015) Metodolohichni pidkhody ta metody doslidzhennia gendernykh pytan v osviti [Methodological approaches and methods of research of gender issues in education]. Henderna paradyhma osvitnoho prostoru. Kryvyi Rig: VTs KHPI DVNZ «KNU», no. 1, pp. 14-16.

2. Palahniuk M.M. (2015) Henderna problematyka: vyklyky suchasnosti [Gender range of problems: challenges of modernity]. Humanitarnyi visnyk Zaporizkoi derzhavnoi inzhenernoi akademii, no. 60, pp. 73-83.

3. Ruban O.V. (2012) Realii ta perspektyvy hendernoho partnerstva v Ukraini na pochatku XXI stolittia (svitohliadnyi aspekt) [Realities and prospects of gender partnership in Ukraine at the beginning of XXI century (world view aspect)]. Kyiv: NAN Ukrainy, p. 33.

4. Voronina O.A. (2014) Hendernerivniannia yak strukturnyi element derzhavnoi polityky v skandynavskykh krainakh [Gender equalization as structural element of public policy in the Scandinavian countries]. Novyi pohliad, no. 4, pp. 133-151.

5. Krotikov V.P., Maliuha V.M., Topalskyi V.L. (2012) Henderna polityka u Zbroinykh Sylakh Ukrainy: problemy teorii ta praktyky [Gender politics in the Armed Forces of Ukraine: problems of theory and practice]. Kyiv: NDTs HP ZSU.

6. Klymenko, N.H. (2014) Rol i mistse zhinky - viiskovosluzhbovtsia v Ukraini [Role and place of woman - serviceman in Ukraine]. Ekonomika i derzhava, pp. 116-119.

7. Martseniuk T. (2016) «Nevydymyi batalion»: uchast zhinok u viiskovykh diiakh v ATO ["Invisible battalion": participating of women in military operations in ATO] (sotsiolohichne doslidzhennia). Available at: http://ekmair.ukma.edu.ua/bitstream/handle/123456789/7746/Martsenyuk_Nevydymyi_bataloin.pdf (accessed 20 November 2021).

8. Holub A. (2017) Oboviazkovyi pryzov zhinok u armiiu: mizhnarodnyi dosvid ta Ukraina [The Obligatory call-up of women: international experience and Ukraine]. Available at: https://uain.press/articles/obovyazkovyj-pryzovzhinok-u-armiyu-mizhnarodnyj-dosvid-ta-ukrayina-605256 (accessed 21 November 2021).

9. Chy potribni zhinky na viini? [Are there necessary women on war?] Available at: http://www.zhinka-online.com.ua/ ukrajinska-zhinka/zhinka-v-armiji/342-chy-potribni-zhinky-na-viini (accessed 21 November 2021).

10. Vetrov I. (2016) Zhinky v armii: ZSU i svitovyi dosvid [Women in an army: AFU and world experience]. Available at: https://ukraine.segodnya.ua/ua/ukraine/zhenshchiny-v-armii-vsu-i-mirovoy-opyt-689801 (accessed 21 November 2021).

11. Krotykov V.P., Maliuha V.M., Topalskyi V.L. (2011) Aktualni problemy hendernoi polityky Zbroinykh syl Ukrainy [Issues of the day of gender politics of Armed forces of Ukraine]: navch. posibnyk / za zah. red. Andresiuka B.P. Kyiv: NDTs HP ZS Ukrainy, 112 p. (in Ukrainian) 